\title{
ANALYSIS OF FACTORS INFLUENCING THE PERFORMANCE OF PLANTATION WORKERS IN THE TLOGO PLANTATION SEMARANG REGENCY
}

\author{
Gerardine Widyaswari Pradipta \\ Email: gerardine.widyaswari@gmail.com \\ Wulan Sumekar \\ Universitas Diponegoro \\ Bambang Trisetyo Eddy \\ Universitas Diponegoro
}

Program Studi S1 Agribisnis Universitas Diponegoro

\begin{abstract}
This study aimed to analyze the performance of plantation workers and analyze the factors affecting the performance of plantation workers. The research was conducted at Tlogo Plantation in Semarang Regency. The research was conducted using survey method. The respondents were selected 50 people from 123 people by simple random sampling. The data were analysed using multiple linear regression. The results showed that $72 \%$ of the plantation workers had a moderate production and $68 \%$ of the plantation workers had been able to meet the company's work targets. Based on multiple linear regression test, simultaneously got the value of $\mathrm{F}$ equal to 3,369, the value was bigger than $\mathrm{F}$ table value that is 2,58 , so simultaneously, motivation, competence, discipline, and environment influence to plantation workers performance. These factors affected performance by $23 \%$, the rest was influenced by other factors beyond motivation, competence, discipline, and environment. Partial test showed that the level of significance of competence, environment, motivation, and discipline respectively were $0.010 ; 0.114 ; 0.218$; and 0.693 . These values indicated that there was significant influence for competence, while for motivation, discipline, and environment there were no significant effect.
\end{abstract}

\section{Keywords:}

Competence; discipline; environment; motivation; performance.

Received: 16 Januari 2018 ;

Accepted: 09 Februari 2018;

Publish; Maret 2018

\section{How to Cite:}

Pradipta, G.W., Sumekar, W., \& Eddy, B.T.. (2018). Analysis of Factors Influencing The Performance of Plantation Workers in The Tlogo Plantation Semarang Regency.

Econosains, 16(1), 


\section{INTRODUCTION}

Rubber is one of the plantation crops that are widely cultivated in Indonesia. The area of rubber in 2015 ranks second after palm oil with $3,621,100 \mathrm{Ha}$, followed by coconut, cocoa, coffee, sugar cane, tobacco and tea (Badan Pusat Statistik, 2015). Rubber production in Indonesia also ranks second after palm oil by 3,145,400 tons in 2015, followed by coconut, sugar cane, coffee, cocoa, tobacco and tea (Badan Pusat Statistik, 2015). Therefore, rubber is an important commodity to be cultivated more widely. Workers working in the plantation workers sector are called plantation workers. Plantation workers jobs do not require a high level of education. However, it requires good skill, so the rubber produced will be plenty and with good skill, the plantation workers will not damage the rubber trees. Indonesia has 655,998 workers working on plantations in 2013, the figure has a percentage of $1.67 \%$ of the total workforce in agriculture, plantation, forestry, hunting and fisheries (Badan Pusat Statistik, 2014).

Factors that affect the performance are 2 internal and external, internal factors such as knowledge, skills, work experience, and supported by a strong motivation of the employee, while external factors are much influenced by the environment (Khoir, 2012). Another factor that affects employee performance is the competence or ability possessed by employees (Mangkunegara, 2010). Types of competence include skills, knowledge, social roles, self-image, trait, and motives (Rivai and Sagala, 2009).

Another factor affecting performance is the discipline of work which is the most dominant factor in affecting employee performance and performance because the discipline of work makes the employees do a good social adjustment, obey all rules, perform corrective action, and effective in work (Ginting, 2013). Tlogo Plantation is a local government-owned company so that the factors that affect the performance becomes very important to be analyzed so that later can evaluate the performance of plantation workers so that productivity will increase as the impact of increasing the performance of plantation workers.

This study aimed to analyze the performance of plantation workers and analyze the factors affecting the performance of plantation workers.

\section{LITERATURE}

\section{Performance}

Performance is the result of work, both in quantity and quality achieved by the workforce or employees in carrying out the tasks assigned responsibly (Ginting, 2013). Performance is high if the work target has been completed by not exceeding the time limit provided (Hadari, 2006). Performance is the result achieved by the workforce in completing the work given based on experience, skills, time, and sincerity (Hasibuan, 2006). Performance criteria include attitudes, behavior, and output (Schuler and Jackson, 1999).

Production criteria have a focus on what has been generated compared to how something can be generated, criteria based on results are appropriate if the company does not care how something can be produced (Schuler and Jackson, 1999).

\section{Motivation}

Motivation is the process by which one's efforts are directed, energized, and sustained for a goal to be achieved (Robbins and Mary, 2010). Motivation serves as a driving force for people to do something. Motivation can serve as something that determines a person's actions according to his pur- 
pose. Another function of motivation is to select behavior by eliminating actions that are no longer useful for organizational purposes (Sardiman, 2007).

Matters affecting motivation in working, among others, a sense of security in work, a fair pay system, rewards for achievement of work have been achieved, and fair treatment of the company (Rivai and Sagala, 2009). Pattern of motivation can be achievement motivation, affiliation motivation, competence motivation, and power motivation (Hamid, 2014).

\section{Competence}

Competence is a skill, knowledge, ability, and skill, which can be a requirement for doing a job (Dessler, 2004). Competence has characteristics that are something that becomes part of one's character and become part of one's behavior in carrying out the work (Mangkunegara, 2010). Matters affecting competence include skills, beliefs and values, personality characteristics, experience, emotional issues, motivation, organizational culture, and intellectual ability (Wibowo, 2012).

There are two types of competence, soft competencies (referring to the competence that is difficult to calculate because it is related to tacit knowledge, for example leadership) and hard competencies (more technical nature so easy to count) (Budihardjo, 2011).

\section{Discipline}

Discipline is labor and group compliance with orders and has the initiative to do what is necessary even if no orders from superiors (Heidjrachman, 2002). Aspects of work discipline include attendance, work time, obedience to orders, compliance with rules, work productivity, and uniform use (Amriany, et al., 2004).
Things that affect the discipline of work, among others, the presence or absence of exemplary leaders in the company, the size of the compensation or wages, the presence or absence of certain rules that can be used for employment, courage leaders in taking action, whether or not attention to labor, the lack of leadership oversight, and the creation of habits that support the establishment of the discipline of work (Sutrisno, 2009).

\section{Work Environment}

Work environment is everything that is around the workforce, which can affect the workforce in carrying out its duties. Work environment factors such as office physical condition, interaction between labor, and things that can improve the atmosphere of safe and comfortable, and generate work morale that affect the performance (Dhermawan et al., 2012). Work environment factors can also be psychic which includes overwork, poor monitoring systems, frustration, changes in all forms, and disagreements between individuals and groups (Suwatno and Priansa, 2011).

Work environment needs to be considered in maintaining the existence of success to achieve optimal performance, meaning that success or failure in work is also influenced by how people or organizations can cope with environmental influences, the task of competition will be able to motivate someone to perform better to be superior to the resources other human beings, this can happen if in the human resources it also has and realizes the need for the development of an insight of excellence (Hamid, 2014).

\section{METHOD}

This research was conducted in October 2017 at Tlogo Plantation, Semarang Regency. The research method used is survey. 
This study took a sample of 50 people from a total population of 123 people by using simple random sampling. Determination of the number of samples conducted when the research conducted correlation analysis or regression, then the number of members of the sample studied at least 10 times the number of variables studied (Sugiyono, 2008). The variables studied were 5 , then the variable multiplied by 10 .

Data collection was done through questionnaires with assisted interview, observation, and literature study. The questionnaire contained a statement and provided 5 possible answers arranged in order to match the Likert Scale. Observation is done by observing and noting important things related to research data. Library study is done by comparing the data that has been obtained with the existing literature in the study.

Data analysis method used is descriptive quantitative method. Methods of descriptive data analysis with a quantitative approach used when the study aims to describe and explain an event that occurred at the present time in the form of meaningful numbers. The quantitative analysis used is Multiple Linear Regression.

The methods used to measure the variables of performance, motivation, discipline, and work environment and group them into three strata namely, high, medium, and low by using the average formula and standard deviation. According Budiarto (2001) how to find the average is to use the formula:

$\sum \mathrm{XN}$

Information:

$\sum \mathrm{X}=$ total variable score

$\mathrm{N}=$ number of plantaion workers

Standard deviation formula:

$\sum \mathrm{X} 2 \mathrm{~N}-\left(\sum \mathrm{XN}\right) 2$

Information:

$\mathrm{SD}=$ Standard deviation $\sum \mathrm{X} 2 \mathrm{~N}=$ Each score squared then

summed then divided by $\mathrm{N}$

$\left(\sum \mathrm{XN}\right) 2=$ Average squared

\section{DISCUSSION}

\section{Characteristics of Respondents}

Respondents in this study consist of various characteristics. Characteristics of respondents in this study were, age, gender, education level, number of family members, length of work, and occupation. Characteristics of respondents in this study can be seen in Table1.

Table1. Number and Percentage of Plantation Workers Based on Respondent Characteristics

\begin{tabular}{|c|c|c|}
\hline Characteristics & $\mathrm{N}$ & Percentage \\
\hline \multirow{2}{*}{\multicolumn{3}{|c|}{--people-- }} \\
\hline & & \\
\hline$\leq 30$ & 3 & 6 \\
\hline $31-40$ & 11 & 22 \\
\hline$-41-50$ & 13 & 26 \\
\hline$->50$ & 23 & 46 \\
\hline \multicolumn{3}{|l|}{ Gender } \\
\hline Men & 45 & 90 \\
\hline Women & 5 & 10 \\
\hline \multicolumn{3}{|l|}{ Education } \\
\hline No education & 3 & 6 \\
\hline EM & 29 & 58 \\
\hline JHS & 14 & 28 \\
\hline SHS & 4 & 8 \\
\hline \multicolumn{3}{|l|}{$\begin{array}{c}\text { Family mem- } \\
\text { bers }\end{array}$} \\
\hline$\leq 4$ & 34 & 68 \\
\hline$>4$ & 16 & 32 \\
\hline \multicolumn{3}{|l|}{ Length of work } \\
\hline$<1$ & 3 & 6 \\
\hline $1-10$ & 24 & 48 \\
\hline $11-20$ & 13 & 26 \\
\hline $21-30$ & 7 & 14 \\
\hline$>30$ & 3 & 6 \\
\hline \multicolumn{3}{|l|}{ Occupation } \\
\hline Primary & 46 & 92 \\
\hline Side job & 4 & 8 \\
\hline
\end{tabular}

Respondents working at Tlogo Plantation have varying ages, the youngest aged 28, while the eldest is 67 years old. Age is more than 15 years which is the productive age to work. This is in line with Agusmidah's (2010) opinion that workers are people 
who have entered the productive age (15 years and over) and are already or are working, or may be looking for work.

Respondents who work in Tlogo Plantation are mostly male as many as 45 people. This is because this work requires a strong force, especially when transporting rubber latex reaches tens of liters to the rubber collection point or to the processing place. This is in accordance with the opinion of Khotimah (2009) which states that the work for men is generally adapted to the biological, psychological, and social of men who are strong and have a higher level of employment risk.

Respondents working in Tlogo Plantation majority have educational background only to elementary school. This is because during recruitment, the company does not demand plantation workers to have a high educational background. At the time of recruitment, the company will provide training in advance.

Respondents working in Tlogo Plantation have a majority of family members amounting to less than four that is equal to $68 \%$. The number of family members affected the performance of the plantation workers, because the more the number of family members, the desire of a person to have a job will increase to meet daily needs.

Respondents working in Tlogo Plantation have varying length of work, some are less than a year to 37 years old. Plantation workers who worked less than a year have a variety of reasons, such as, moving from previous jobs and looking for work near the house, or have retired from previous jobs so look for work that has no age limit to work. While the plantation workers who have 37 years of work experience are plantation workers who already feel comfortable working in Tlogo Plantation or who do not have other work options so decided to keep working there. Another factor that causes plantation workers to have long-term work experience in Tlogo Plantation is because the longer the working time the plantation workers will be more skilled, so the plantation workers are needed by the company. This is in accordance with Suindri's opinion, et al. (2013) which states that the longer the workforce do the same job continuously the work will be faster completed and the more skilled the workforce.

Respondents working in the Tlogo Plantation majority considered working in Tlogo Plantation as the main job and had side jobs such as finding livestock feeds at home or owning small businesses. Therefore, when there is an empty hour break of 7 to 10 , the plantation workers go back to their homes to do other work, but some remain on the land because the land where they work is far from their homes and they have no vehicles, so choose to stay on the ground until the time to collect the rubber arrived.

\section{Performance of Plantation Workers}

The performance of plantation workers is measured on the basis of the production of rubber crops. This is done because the company only focuses on the amount of production. This is in line with Schuler and Jackson (1999) suggesting that production criteria focus on what has been produced compared to how something can be generated, criteria based on results are appropriate if the company does not care how something can be produced.

The production of plantation workerss varies, of which at least $39.1 \mathrm{~kg}$ and the most are $181.9 \mathrm{~kg}$. Based on the calculation, obtained average value $101.372 \mathrm{~kg}$ per September and the standard deviation of 30,469 . Production results are grouped into 3 levels, high, medium, or low. Production can be said to be high if more than 131,841 . The production can be said to 
be low if it has a value less than 70.903. The production can be said to be medium if the value is between 70.903 to 131.841 . Based on the calculation results obtained data production respondents that can be seen in Table 2 .

Table 2. Number and Percentage of Plantation workers Based on Production Results

\begin{tabular}{|l|c|c|}
\hline Production & N & Percentage \\
\hline & --people-- & $--\% 0^{--}$ \\
\hline High & 7 & 14 \\
\hline Medium & 36 & 72 \\
\hline Low & 7 & 14 \\
\hline
\end{tabular}

The results of production in Table 2 are the production of respondents in September. The production of tapping rubber is classified as moderate because $72 \%$ of plantation workers have production between $70.903 \mathrm{~kg}$ to 131.841. However, there are still $14 \%$ of plantation workers whose production is low. This is because the plantation workers include daily freelancers who work not every day and often do not come to work, so the results generated per month is still low.

The performance of plantation workers in this study was calculated based on rubber tapping production. The production can determine the performance of the plantation workers. This is in accordance with the opinion of Schuler and Jackson (1999) which states that performance criteria include attitudes, behaviors, and production results.

There are many plantation workers that can exceed the job target given by the company. The work target set by the company is $3 \mathrm{~kg}$ per day, if multiplied by 30 days it will produce $90 \mathrm{~kg}$ per month. Plantation workers that can exceed the target by $68 \%$. Working hours provided by the company have also been used maximally by the plan- tation workers, so they can complete the work on time, even before working hours run out. It can be set as a high performance. This is in accordance with the opinion of Hadari (2006) which states that Performance is high if the work targets have been completed by not exceeding the time limit provided.

\section{Factors Influencing The Perfor- mance}

Based on the data that has been analyzed, obtained the coefficient of determination and the value of $\mathrm{F}$ as follows.

Table 3. Coefficient of Determination and Value off

\begin{tabular}{|l|c|c|c|}
\hline Model & R & R Square & $\mathrm{F}$ \\
\hline 1 & $.480^{\mathrm{a}}$ & .230 & - \\
Regression & - & - & 3.36 \\
& & & 9 \\
\hline
\end{tabular}

The coefficient of determination (R2) is 0,230 or $23 \%$. This shows that motivation, competence, work discipline, and environment influence performance by $23 \%$, the rest or $77 \%$ are other factors that affect performance. $\mathrm{F}$ test (simultaneous) is used to test the influence of independent variables simultaneously to the dependent variable. This is in accordance with the opinion Sugiyono (2008) which states that the F test is used to test the independent variables together against the dependent variable. The result of analysis through $F$ test is 3,369 , the value is bigger than $\mathrm{F}$ table value that is 2.58 , so motivation, competence, work discipline, and environment influence simultaneously to performance.

Based on data that has been analyzed through multiple linear regression test, obtained the following results, 
Table 4. Multiple Linear Regression Test

\begin{tabular}{|l|c|c|c|}
\hline Model & $\mathrm{B}$ & $\mathrm{T}$ & Sig. \\
\hline (Constant) & -103.463 & -1.541 & .130 \\
Motivation & 2.388 & 1.249 & .218 \\
Competence & 2.610 & 2.701 & .010 \\
Discipline & -.786 & -.397 & .693 \\
Environtment & 1.639 & 1.614 & .114 \\
& & & \\
& & & \\
& & & \\
& & & \\
& & & \\
\end{tabular}

Based on table 4 , we get the result of equation $\mathrm{Y}=-103,463+2,388$ $\mathrm{X} 1+2,610 \mathrm{X} 2-0,786 \mathrm{X} 3+1,639 \mathrm{X} 4$ + e. The value of negative constant shows that by assuming no independent variable, performance tends to decrease. The value of the positive regression coefficient indicates that assuming no other independent variables, if the independent variable has increased, then the performance tends to increase. The value of the negative regression coefficient shows that assuming no other independent ariabel, if the variable has increased, then the performance tends to decrease.

\section{Motivation}

Based on the calculation, got the average value of motivation of 34.08 and the standard deviation value of motivation of 3.10. Motivation can be said to be high if more than 37.18. Motivation can be said to be low if it has a value less than 30.98. Motivation can be said to be if the value is between 30.98 to 37.18 . Based on the calculation results obtained categories of motivation of respondents that can be seen in Table 5 .
Table 5. Number and Percentage of Plantation

Workers Based on Motivation Scores

\begin{tabular}{lcc}
\hline $\begin{array}{l}\text { Motiva- } \\
\text { tion }\end{array}$ & $\mathrm{N}$ & Percentage \\
\hline & --people-- & $--\%$-- \\
High & 10 & 20 \\
Medium & 34 & 68 \\
Low & 6 & 12 \\
\hline
\end{tabular}

Based on Table 5, the motivation of plantation workers is dominated by medium category of $68 \%$. The motivation of the plantation workers was also measured on the basis of the score given 8 statements and provided 5 possible answers, the higher the score, the higher the motivation will be. The achievement of plantation workers is high because all the plantation workers have a score of 4 and 5 . The result of plantation workers work is quite satisfactory because all the plantation workers have a score of 4 and 5. Plantation workers feel their dedication in the company has been recognized, although there are still some plantation workers who disagree against the statement. The persistence of the plantation workers is already high because the score is dominated by 4 and 5. The plantation workers are working hard because the 4 and 5 scores dominate the answers of the plantation workers. Plantation workers feel the company needs to provide motivation to encourage morale. Some plantation workers are still not ready to be given greater responsibility, this is indicated by the still score of 3 in the answer. 
Based on table 4 , the results of the analysis through the partial test obtained Sig value. motivation of 0.218 . The result shows that Ho is accepted and $\mathrm{Ha}$ is rejected because $0,218>0,05$, so it can be concluded that motivation has no effect on rubber planter performance in Tlogo Plantation. This is because plantation workers assume that the payroll system is not fair, there is no health insurance facility for daily workers so that it does not generate a sense of security in the work, and the company's policy is not fair. Because of the inconsistency between the expectations of the plantation workers and the company policy, the motivation does not affect the performance, whereas those things that affect the high and low of a motivation. This is in line with Rivai and Sagala (2009) statements which state that matters affecting motivation in work include, a sense of security in the workplace, a fair pay system, rewards for achievement of work achieved, and fair treatment of the company.

\section{Competence}

Based on the calculation, the average competence score is 31.48 and the standard deviation score of 4.16 . Competence can be said to be high if more than 35.46. Competence can be said to be low if it has a value less than 27.32. Competence can be said to be if the value is between 27.32 up to 35.46 . Based on the calculation results obtained categories of competence of respondents that can be seen in Table 6 .

Table 6. Number and Percentage of Plantation

\begin{tabular}{|l|c|c|}
\hline Compentence & $\mathrm{N}$ & Percentage \\
\hline & --people-- & $--\%$-- $^{-}$ \\
\hline High & 8 & 16 \\
\hline Medium & 37 & 74 \\
\hline Low & 5 & 10 \\
\hline
\end{tabular}

workers Based on Competence Score

Based on Table 6, plantation workers with moderate competence of $74 \%$. This is because competence is not measured by skill only, but from the aspect of knowledge and education. The skill of the plantation workers could have been expert. However, knowledge and low education will still affect the competency score. Competence can also be measured on a score with 9 statements and provided 5 possible answers, the higher the score, the higher the competence will be. Some plantation workers assume that their work is not in accordance with the knowledge and level of education they have, this is indicated by the number of scores 2 and 3 on the answers given by the plantation workers. This rubber tapping job still lacks the skills they had before. However, after training and having long work experience, their skills have improved. Plantation workers have been able to reduce errors in work in accordance with the answers dominated by the score 4 . The confidence of the plantation workers is still less because it is still dominated by 2 and 3 scores. However, they feel the ability to work is above average. Some plantation workers are still struggling to find a way out of the obstacles they face. However, they can respond well to criticism, so they can take appropriate action on the criticism.

Based on table 4 , the results of the analysis for competence through $\mathrm{t}$ test obtained Sig value. of 0.010 . The value is smaller than 0.05 , so the competence affects the performance of the plantation workers. Competence affects the performance of plantation workers because techniques to tap rubber will affect the performance measured by the production. If when tapping a mistake, then the production of rubber will decrease. Therefore, in the young rubber plantations that have been produced, Tlogo Plantation employs highly 
skilled and expert plantation workers to minimize errors. Skill is one of the things that affect the high competence of a person. This is consistent with Wibowo's (2012) statement which states that matters affecting competence include, beliefs and values, skills, experience, personality characteristics, motivation, emotional issues, intellectual ability, and organizational culture.

\section{Discipline}

Based on the calculation, got the average value of work discipline of 32.70 and the standard deviation of the discipline of work of 2.99. Work discipline can be said to be high if more than 35.69. Work discipline can be said to be low if it has a value of less than 29.71. Work discipline can be said to be if the value is between 29.71 to 35.69. Based on the calculation results obtained value category Discipline of work respondents that can be seen in Table 7.

Table 7. Number and Percentage of Plantation

\begin{tabular}{|l|c|c|}
\hline Discipline & N & Percentage \\
\hline & ---people--- & $---\%---$ \\
\hline High & 10 & 20 \\
\hline Medium & 33 & 66 \\
\hline Low & 7 & 14 \\
\hline
\end{tabular}

Workers Based on Discipline Score

Based on Table 7, the plantation workers have a moderate work discipline score of $66 \%$. The work discipline of the plantation workers is measured on the basis of the score given 8 statements and provided 5 possible answers, the higher the score, the higher the work discipline. Plantation workers obey the rules given by the company because the score is dominated by the numbers 4 and 5 . Still quite a lot of plantation workers who do not come on time because the score is dominated number 3. Plantation workers have worked in accordance with the work schedule provided by the company. The plantation workers have completed the work on time. The plantation workers feel the time given by the company to complete the work is appropriate. The distance between the residence and the workplace does not affect the presence of the plantation workers, as evidenced by the number of scores 4 and 5 in the answer. The plantation workers do not leave the workplace during working hours, this is evidenced by the score 4 and 5 in the answer. The plantation workers always tell the employer if they do not come to work.

Based on table 4 , the result of $t$ test analysis for work discipline, obtained Sig value. 0.693, the value is greater than 0.05 , so the work discipline does not affect the performance of the plantation workers. This is because even though the rubber plantation is late, but the work schedule to tap the rubber specified by the company is quite long and is the right time when the turgor pressure from the rubber trees is at a maximum of 4 am to 7 am which causes the amount of latex that flows and time waiting for latex long enough so that before the time specified to collect latex, latex has stopped flowing. This is in accordance with the opinion of Ulfah, et al. (2015) which states that at 6-7 am, latex production is higher than at 9-10 am. Turgor pressure affects much of the least of the flowing latex. This is consistent with the opinion of Setiawan and Andoko (2008) which states that latex leads indicate the presence of turgor pressure in the latex vessel file, turgor pressure is the pressure that occurs on the cell wall caused by the cell contents, the amount of cell contents corresponds to the amount of pressure on the cell walls, strong turgor pressure causes more and more latex to flow. 


\section{Work Environment}

Based on the calculation, the average score of the working environment score is 40.86 and the standard deviation of work environment is 3.95. Work environment can be said to be high if more than 44,81. The work environment can be said to be low if it has a value less than 36.91. The working environment can be said to be if the value is between 36.91 to 44.81 . Based on the calculation results obtained the category of work environment respondents who can be seen in Table 8 .

Table 8. Number and Percentage of Plantation Workers Based on the Work Environment Score

\begin{tabular}{|l|c|c|}
\hline $\begin{array}{l}\text { Work Envi- } \\
\text { ronment }\end{array}$ & $\mathrm{N}$ & Persentase \\
\hline & -people- & $--\% 0^{--}$ \\
\hline High & 11 & 22 \\
\hline Medium & 28 & 56 \\
\hline Low & 11 & 22 \\
\hline
\end{tabular}

According to Table 8, plantation workers with a working environment score of $56 \%$. The working relationship between plantation workers has been well established, this is proved by the dominance of the score 4 and 5. The plantation workers also assume colleagues can work well together. It also affects the sense of comfort at work, a good relationship will create a sense of comfort while working. This is in accordance with the opinion of Dhermawan, et al. (2012) which states that the work environment factors in the form of physical office conditions that include lighting, air temperature, interaction between workers, and things that can improve morale and affect the performance of a person. All the plantation workers also appreciate each other. However, there are still many plantation workers who think that the policy of the company has not pay attention to the rights and obligations of plantation workers. The pattern of leadership is also less favored by the plantation workers. The plantation workers also feel the company is still not being fair. However, plantation workers establish good relationships with superiors. Plantation workers can also adapt to the work environment at the Tlogo Plantation Company.

Based on table 4 , the result of $t$ test analysis for work environment, obtained Sig value. 0.114, the value is greater than 0.05 , so the working environment does not affect the performance of the plantation workers. This is because according to the plantation workers, even though they are comfortable with co-workers or with superiors, but not necessarily it makes them to the spirit of work. Whereas it should be a comfortable working environment to make the plantation workers more enthusiasm in work. This is in accordance with the opinion of Dhermawan, et al. (2012) which states that the work environment is everything that exists around the worker, which can affect him in carrying out the task, work environment factors can be interaction between workers, and things that can improve the atmosphere conducive and morale and affect the one's performance.

\section{CONCLUSION AND SUGGES- TION}

\section{Conclusion}

Based on the results of the study, the conclusions of this study are as follows:

1. Plantation workers that have a relatively moderate production of $72 \%$ and as many as $68 \%$ of plantation workers have been able to meet the company's work targets.

2. Factors that affect performance as measured by simultaneous tests show that, motivation, competence, 
work discipline, and work environment affect the performance of plantation workers. These factors affect performance by $23 \%$, the rest is influenced by other factors beyond motivation, competence, work discipline, and work environment. Partial tests show that only competencies affect performance. Motivation, work discipline, and work environment do not affect the performance of the plantation workers.

\section{Suggestion}

Based on the results of research on the analysis of factors affecting the performance of the plantation workers in the Tlogo Regency Plantation Company of Semarang Regency, the suggestion for plantation workers is to improve the competence or skill in tapping rubber so that the performance measured based on the rubber production will increase. Suggestion for Tlogo Plantation is to conduct regular training for plantation workers in tapping rubber trees, so that plantation workers will be more skilled in rubber tapping.

\section{BIBILIOGRAPHY}

Agusmidah. 2010. Dinamika Hukum Ketenagakerjaan. USU Press, Medan.

Amriany, F., Y. Probowati, dan G. Atmadji. 2004. Iklim organisasi yang kondusif meningkatkan kedisiplinan kerja. J. Anima. 19 (2): 179-193.

Badan Pusat Statistik. 2014. Jumlah Tenaga Kerja Perusahaan Perkebunan Menurut Provinsi Tahun 2013. (https://www.bps.go.id/ statictable/2014/08/19/1673/jumlahtenaga-kerja-perusahaan-perkebunanmenurut-provinsi-tahun-2013.html). Diakses tanggal: 14 Januari 2018.

Badan Pusat Statistik. 2015. Luas tanaman perkebunan menurut propinsi dan jenis tanaman, Indonesia (000 ha), 2012-2015. (https://www.bps.go.id/ dynamictable/2015/09/04/838/luas- tanaman-perkebunan-menurut-propinsidan-jenis-tanaman-indonesia-000-ha2012-2015-.html). Diakses tanggal: 18 Desember 2017.

Badan Pusat Statistik. 2015. Produksi tanaman perkebunan menurut propinsi dan jenis tanaman, Indonesia (000 ton), 2012-2015. (https:// www.bps.go.id/ dynamictable/2015/09/04/839/produksi -tanaman-perkebunan-menurut-propinsi -dan-jenis-tanaman-indonesia-000-ton2012-2015-.html). Diakses tanggal: 18 Desember 2017.

Budiarto, E. 2001. Biostatistika Untuk Kedokteran dan Kesehatan Masyarakat. EGC, Jakarta.

Budihardjo, A. 2011. Organisasi Menuju Pencapaian Kinerja Optimum Sintesis Teori Untuk Mengungkapkan "Kotak Hitam" Organisasi. Prasetiya Mulya Publishing, Jakarta.

Dessler, G. 2004. Manajemen Sumber Daya Manusia. Prenhallindo, Jakarta.

Dhermawan, A. A. N. B., I. G. A. Sudibya, dan I. W. M. Utama. 2012. Pengaruh motivasi, lingkungan kerja, kompetensi, dan kompensasi terhadap kepuasan kerja dan kinerja pegawai di lingkungan Kantor Dinas Pekerjaan Umum Provinsi Bali. J. Manajemen, Strategi Bisnis dan Kewirausahaan. 6 (2): 173-184.

Ginting, E. S. 2013. Analisis Faktor - Faktor yang Mempengaruhi Kinerja Penderes Kebun Batang Toru PT. Perkebunan Nusantara III (PERSERO). Program Studi Magister Manajemen, Program Pascasarjana, Universitas Terbuka, Jakarta. (Tesis Magister Manajemen).

Hamid, S. 2014. Manajemen Sumber Daya Manusia Lanjutan. Deepublish, Yogyakarta.

Hadari, N. 2006. Evaluasi dan Manajemen Kinerja di Lingkungan Perusahaan dan Industri. Gadjah Mada University Press, Yogyakarta.

Heidjrachman, H. S. 2002. Mana- 
jemen Personalia. BPFE UGM, Yogyakarta.

Kementrian Perindustrian. 2007. Gambaran Sekilas Industri Karet. Kementrian Perindustrian, Jakarta.

Khoir, D. H. 2012. Faktor Faktor yang Mempengaruhi Kinerja Pegawai Pada Direktorat Pembinaan Sekolah Dasar Ditjen Pendidikan Dasar Kemdikbud. Program Pascasarjana Ilmu administrasi, Fakultas Ilmu Sosial dan Ilmu Politik, Universitas Indonesia, Jakarta. (Tesis Magister Administrasi).

Khotimah, K. 2009. Diskriminasi gender terhadap perempuan dalam sektor pekerjaan. J. Studi Gender\&Anak. 4 (1): 158-180.

Mangkunegara, A. P. 2010. Manajemen Sumber Daya Manusia Perusahaan. Remaja Rosdakarya, Bandung.

Rivai, V. dan E. J. Sagala. 2009. Manajemen Sumber Daya Manusia Untuk Perusahaan : Dari Teori ke Praktik. Rajawali Pers, Jakarta.

Robbins, S. P. dan C. Mary. 2010. Manajemen. Erlangga, Jakarta.

Sardiman, A. M. 2007. Interaksi dan Motvasi Belajar Mengajar. Rajawali Pers, Bandung.

Schuler, R. S. dan S. E. Jackson. 1999. Manajemen Sumber Daya Manu- sia Menghadapi Abad Ke-21. Erlangga, Jakarta. (Diterjemahkan oleh A. Rosyid dan P. R. Y. Pasla).

Setiawan, D. H. dan A. Andoko. 2008. Petunjuk Lengkap Budi Daya Karet. AgroMedia Pustaka, Jakarta. Sugiyono. 2008. Metode Penelitian Kuantitatif Kualitatif dan R\&D. Alfabeta, Bandung.

Sutrisno, E. 2009. Manajemen Sumber Daya Manusia. Kencana Prenada Media Group, Jakarta.

Suwatno dan D. J. Priansa. 2011. Manajemen SDM dalam Organisasi Publik dan Bisnis. Alfabeta, Bandung.

Suindri, N. N., N. W. Ariyani, dan J. Mauliku. 2013. Pengaruh indeks prestasi kumulatif, masa kerja, dan pelatihan terhadap kinerja bidan lulusan politeknik kesehatan Denpasar jurusan kebidanan. J. Skala Husada. 10 (1): 47-53.

Ulfah, D., A. R. Thamrin, dan T. W. Natanael. 2015. Pengaruh waktu penyadapan dan umur tanaman karet terhadap produksi getah (lateks). J. Hutan Tropis. 3 (3): 247-252.

Wibowo. 2012. Manajemen Kinerja. Rajawali Pers, Jakarta. 